\title{
Evaluation of Fatty acid Composition and Antimicrobial Activity of Eight Medicinal Plants from Kashmir
}

\author{
ZUBAIR REHMAN NENGROO ${ }^{1}$, ABDUL RAUF ${ }^{*}$, MOHAMMAD DANISH ${ }^{2}$, \\ and MUZAMMIL SHARIEF DAR ${ }^{3}$
}

\begin{abstract}
${ }^{1}$ Department of Chemistry, Aligarh Muslim University, Aligarh 202002, Uttar Pradesh, India.
Department of Botany, Aligarh Muslim University, Aligarh 202002, Uttar Pradesh, India.

${ }^{3}$ Department of Microbiology, Aligarh Muslim University, Aligarh 202002, Uttar Pradesh, India.

${ }^{\star}$ Corresponding author E-mail: abduloafchem @ gmail.com
\end{abstract}

http://dx.doi.org/10.13005/ojc/360107

(Received: November 30, 2019; Accepted: January 15, 2020)

\begin{abstract}
The seeds of Abrus precatorius Linn., Amaranthus virdis Linn., Bunium persicum Boiss., Dioscorea deltoidea Wall. Ex Griseb., Malva neglecta Wall., Podophylum hexandrum Royle., Robina pseudoacacia Linn. and Teraxacum officinale Weber were used for fatty acid composition and antimicrobial activity. By GC-MS analysis, the petroleum extracts of seed were rich in oleic acid with $60.2 \%, 58.9 \%$ and $57.5 \%$ for $A$. precatorius, $A$. virdis and $P$. hexandrum respectively. Linoleic acid was dominant in M. neglecta $57.4 \%$, T. officinale $59.0 \%$ and $R$. pseudoacacia $45.6 \%$ and petroselinic acid in B. persicum $64.0 \%$. The defatted seed extracts showed strong inhibition zones in (mm) against fungus Aspergillus niger (14.50-19.53 with nystatin 20.36), Aspergillus fumigates (18.03-21.06 with nystatin 25.56) and Penicellium marneffei (20.97-24.96 with nystatin 28.50) and strongest MIC values $(\mu \mathrm{g} / \mathrm{ml})$ of 150, 250 and 500 against bacteria Esxherichia coli, Staphylococcus aureus and Pseudomonas aeruginosa. This study exhibited beneficial properties of these plants in food and pharmaceutical industries.
\end{abstract}

Keywords: Soxhlet extraction, Gas chromatography-mass spectrometry, Oleic acid, Linoleic acid, Antifungal, Antibacterial.

\section{INTRODUCTION}

Abrus precatorius Linn., Amaranthus virdis Linn., Bunium persicum Boiss., Dioscorea deltoidea Wall. Ex Griseb., Malva neglecta Wall., Podophylum hexandrum Royle., Robina pseudoacacia Linn. and Teraxacum officinale Weber are indigenous plants in Kashmir with low care cost. These plants are found in much abundance with numerous nutritional ${ }^{1,2,3}$ and therapeutic ${ }^{4-10}$ properties. Moreover the seeds of these plants could be an important source of fatty acids and antimicrobial agents. The traditional uses of these plants are given in Table 1. Lipids are the main constituents of food. They are most dominantly found in seeds of plants. The high degree of unsaturated fatty acids present in lipid helps to overcome various cardiovascular diseases ${ }^{26}$. Fatty acids mostly occur in natural fats and plant oils and

This is an Open Access article licensed under a Creative Commons license: Attribution 4.0 International (CC- BY). Published by Oriental Scientific Publishing Company @ 2018

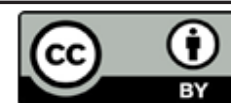


they contain important nutritional and metabolic substances in living organisms ${ }^{27}$. The unsaturated fatty acids linoleic acid and Linolenic acid are very important for human health ${ }^{28}$, while as oleic and linoleic acids can act as vehicles for transfer of other active ingredients, dissolved or dispersed in oil-water type emulsions. The antioxidants could be blended with unsaturated fatty acids to increase their activity e.g. the blends of oleic acid with tocopherol have better protective effect than $\alpha$-tocopherol itself. Moreover replacing saturated fats with unsaturated fats could decrease total and low density (LDL) cholesterol in foods. Excessive use of Antibiotics and synthetic drugs leads to serious health issues both in plants, humans and indirectly to whole food chain which leads to serious problems ${ }^{29}$. There is recent trend in search for the discovery of new drugs which are less expensive, eco-friendly, biodegradable, safer and natural ${ }^{30,31}$. Plants are a source of phytochemicals which can themselves used as pesticides which are biodegradable, less toxic to plants and animals ${ }^{32}$. Therefore keeping in consideration of their much abundance and tremendous biologically properties of $A$. precatorius, $A$. virdis, B. persicum, D. deltoidea, M. neglecta, P. hexandrum, R. pseudoacacia and $T$. officinale these plants were selected for the present work. Therefore we continue our laboratory work wa,34,35 $^{33}$ on seed extracts of these plants. Moreover the defatted extracts of worked seeds were screened for antimicrobial activity and functional group analysis.

Table 1: Characteristics of the worked plants

\begin{tabular}{|c|c|c|c|c|}
\hline S. No. & Common name & Botanical name & Family & Uses \\
\hline 1 & Wanwagun & P. hexandrum Royle & Berberidaceae & $\begin{array}{l}\text { It possesses anti-tumor and anti-oxidant activities }{ }^{11,12,13} \text {. It is Used } \\
\text { in Ayurvedic system in the treatment of diseases like Condylona } \\
\text { acuminate, Taenia capitis, monocytoid leukemia, Hodgkin's } \\
\text { diseases, cancer }{ }^{14,15,16} \text {. }\end{array}$ \\
\hline 2 & Jangli Zeer & B. persicum (Bioss.)B. & Apiaceae & $\begin{array}{l}\text { This plant is used as spice and flavouring agent in foods due to } \\
\text { its earthy aroma }{ }^{17,18} \text {. Seeds are used for treatment of toothache, } \\
\text { dyspepsia, diarrhea and jaundice }{ }^{19} \text {. }\end{array}$ \\
\hline 3 & Shangir & A. precatorius $\mathrm{L}$. & Fabaceae & $\begin{array}{l}\text { Its seeds are used for tuberculosis and painful swellings }{ }^{20} \text {. It is } \\
\text { an excellent source of vitamins, minerals, amino acids and } \\
\text { carbohydrates }{ }^{21} \text {. It is used as aphrodisiac, laxative, bronchodilator, } \\
\text { anti-malarial, anti-convulsant, antioxidant, anti-inflammatory, } \\
\text { analgesic } \\
22,23,24,25\end{array}$ \\
\hline 4 & Hand & T. officinale Weber. & Asteraceae & $\begin{array}{l}\text { This plant is used as a food }{ }^{26} \text {. Its leaf extract is used against } \\
\text { obesity and cardiovascular disease }{ }^{27} \text {. It is used as an anti- } \\
\text { inflammatory medicine }{ }^{28} \text { and to treat infections, bile, liver } \\
\text { problems and diuretic }{ }^{29} \text {. }\end{array}$ \\
\hline 5 & Charleri & A. virdis $\mathrm{L}$. & Amaranthaceae & $\begin{array}{l}\text { Entire plant is used to treat dysentery and inflammation }{ }^{30} \text {. It } \\
\text { possesses anti-oxidant activities }{ }^{31} \text {. }\end{array}$ \\
\hline 6 & Singli Mingli & D. deltoidea Wall. & Dioscoreaceae & $\begin{array}{l}\text { This plant is used to treat various digestive disorders such as } \\
\text { diarrhea, irritability, abdominal pain }{ }^{32} \text {. It is used as traditional } \\
\text { medicine and steroidal drugs in western india }{ }^{33} \text {. }\end{array}$ \\
\hline 7 & Suchal & M. neglecta Wallr. & Malvaceae & $\begin{array}{l}\text { Aerial parts of this are used to treat skin afflications and } \\
\text { gastrointestinal disorders }{ }^{34} . \text { It is used to treat asthma, colds, } \\
\text { digestive, urinary and abdominal problems }{ }^{35} \text {. }\end{array}$ \\
\hline 8 & Kikur & R. pseudoacacia L. & Fabaceae & $\begin{array}{l}\text { The plant is used as an antioxidant, anti-spasmodic, febrifuge, } \\
\text { diuretic, antitumor, antimicrobial and laxative }{ }^{36} \text {. Its leaves are } \\
\text { used for treatment of wounds. }\end{array}$ \\
\hline
\end{tabular}

\section{MATERIALS AND METHODS}

\section{Materials and chemicals}

The seeds of all worked plants were collected from northern parts of Kashmir (India) in September-October 2018. The plants were identified by Dr. Sajad Gangoo and Dr. Tahir Mushtaq, faculty at Forest department, SKAUST-K. Seeds were allowed to dry out at room temperature until they get fully dried. All the chemicals and reagents were purchased from Sigma-Aldrich, USA.

The fungal strains used in this study viz., Aspergillus niger(MTCC-281), Aspergillus fumigates (MTCC-343) and penicillium marneffei (recultured) were obtained from the section of plant pathology, Botany department, Aligarh Muslim University and different strains of bacteria, viz. Escherichia coli 
(ATCC-25922) Pseudomonas aeruginosa (PA01) and Staphylococcus aureus (ATCC-29213) were collected from Agricultural Microbiology Department, Aligarh Muslim University, Aligarh (India).

\section{Soxhlet extraction of seeds}

The seeds of $A$. precatorius, $A$. virdis, $B$. persicum, D. deltoidea, M. neglecta, P. hexandrum, and $R$. pseudoacacia and T. officinale were dried, grinded into powder in mixer grinder. The oil was extracted by using $180 \mathrm{~mL}$ of petroleum ether $\left(40-60^{\circ} \mathrm{C}\right)$ in Soxhlet apparatus (J-SIL Scientific Industries, Agra India). The solvent was evaporated by Rota vapor (Butchi R-300, Mumbai India). The samples were stored at $4^{\circ} \mathrm{C}$ until further use. Defatted seed cakes of all plants were extracted separately with chloroform and methanol $(1 / 1, \mathrm{v} / \mathrm{v})$. The extracts were then dried over anhydrous $\mathrm{Na}_{2} \mathrm{SO}_{4}$, filter and solvent evaporated. These extracts were used for antifungal and antibacterial activities. The extraction time was about 6-8 $\mathrm{h}$ for each extraction. The percentage oil yield (\%) of seed oil was calculated. The analytical values of the seed extracts were determined in accordance with $\mathrm{AOCS}^{36}$.

\section{Synthesis of esters of fatty acid (FAMEs)}

one gram of oil was saponified separately by refluxing with $0.5 \mathrm{~N}$ potassium hydroxide $(\mathrm{KOH})$ solution prepared in ethanol and the reaction was observed in thin layer chromatography (TLC). After completation of reaction, unsaponifiable matter was separated out with diethyl ether and remained part was acidified with $6 \mathrm{~N}$ hydrochloric acid $(\mathrm{HCl})$. Finally diethyl ether was used to separate out the mixed fatty acids (MFAs) in separating funnel.

In second step, of the reaction, MFAs are added with an excess amount of absolute methanol with sulphuric acid as a catalyst. The subsequent mixture was diluted to cloud point by ice chilled water in ice bath. The overall mixture was extracted repeatedly with ether. All the ethereal extracts were washed with $5 \%$ aqueous sodium bicarbonate and they are passed through anhydrous sodium sulphate to yield (FAMEs). Normal column chromatography was used to purify FAMEs and the eluent used was $n$-hexane and diethyl ether $(98 / 2, v / v)$. The FAMEs were identified by Fourier transform infrared spectroscopy (FTIR) as given in (Figure S1).

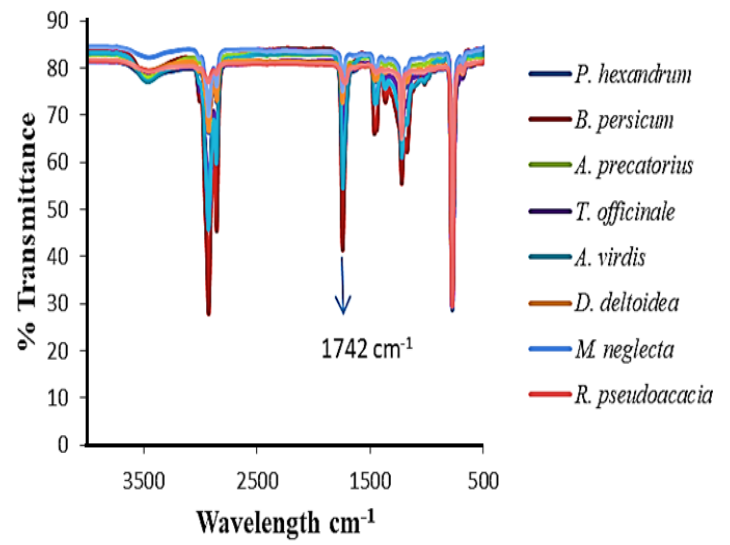

Fig. S1. FTIR spectrum of FAMEs of $P$. hexandrum, B. persicum, A. precatorius, T. officinale, A. virdis, $D$. deltoidea, M. neglecta and $R$. pseudoacacia

\section{Chromatography}

TLC was carried on thin $(0.5 \mathrm{~mm})$ plates of glass $(10 \mathrm{~cm} \times 5 \mathrm{~cm})$ dimensions, which are polished with uniform, layer of silica gel (60-120, Merck, Mumbai, India) formed in ethanol. Petroleum ether/ diethyl ether/acetic acid (80/20/1, v/v) were used as developer in TLC analysis in iodine vapor chamber. The separation of FAMEs was done by column chromatography with silica gel (Merck, Mumbai, India, 60-120 mesh).

\section{Instrumentation}

Fourier Transform Infrared Spectrometer (Perkin-Elmer,UK) fitted with zinc selenide crystal was used for functional group analysis. FAMEs were analyzed by using Gas chromatography (GC, Clarius-680, Perkin Elmer) with flame ionization (FI) and mass spectrometer (MS) as its detectors. Helium was used as a carrier gas, at a flow rate of $0.5 \mathrm{~mL} / \mathrm{min}$ through an Elite- $5 \mathrm{MS}(0.25 \mathrm{~mm} \times 30 \mathrm{~mm})$ capillary column. Oven temperature was initially $180^{\circ} \mathrm{C}$ for $2 \mathrm{~min}$, raised to $200^{\circ} \mathrm{C}$ for $2^{\circ} \mathrm{C} / \mathrm{min}$, to a final temperature of $215^{\circ} \mathrm{C}$ at $2^{\circ} \mathrm{C} /$ minute. injector and detector temperatures are set at $180^{\circ} \mathrm{C}$ and $280^{\circ} \mathrm{C}$ respectively.

\section{Determination of antimicrobial activity Antifungal assay by disc diffusion technique}

The defatted seed extracts were studied for antifungal activity against $A$. fumigatus, $A$. niger and P. marneffi by disc method as per clinical laboratory standards (NCCLS) on filamentous fungi diffusion ${ }^{37}$. The fungal cultures were developed on czapexdox broth (diffco). Twenty $\mathrm{mL}$ of agar media was taken 
into petri dishes and stand to solidify. The lawning of individual fungal strain was prepared on the surface of agar media around the disc. The sterilized discs (6mm in Whatman paper, 42) were transferred in added standard (S, S/2 and S/4) concentrations. A disc without seed extract was used as negative control while as standard nystatin drug was used as positive control. The mycelium mats of $A$. niger, $A$. fumigatus and P. marneffi of old culture (7- day) were washed carefully and kept in normal saline solution. Finally they are filtered aseptically through wool glass. The inoculum was adjusted to $1-5 \times 100 \mathrm{~mL}$, and colony forming units/mL of suspension of test fungi were determined out. The conidial appearance was used for in vitro antifungal assay tests. All the tests were repeated $(\times 3)$. The dishes were incubated at for $48 \mathrm{~h}$ at a temperature of $28^{\circ} \mathrm{C}$ and inhibition zones of fungus $(\mathrm{mm})$ were determined.

\section{Antibacterial activity by broth dilution method}

The antibacterial activity of defatted seed extracts against two gram positive E. coli, S. aureus and Gram negative P. aeruginosa bacteria was done to determine the lowest concentration which inhibit growth entirely also called Minimal Inhibitory Concentration (MIC) by broth dilution method ${ }^{38}$ with a concentration of $10^{4} \mathrm{CFU}$. Initially the samples were diluted in Muller Hinton medium with a concentration $500 \mu \mathrm{g} / \mathrm{mL}$, which were serially and subsequently diluted to attain 250, 125, 62.5 and $31.25 \mu \mathrm{g} / \mathrm{mL}$ concentrations. Ten microliters of bacterial cultures were added to each. After $20 \mathrm{~h}$ of incubation at $37^{\circ} \mathrm{C}$.

\section{Statistical analysis}

Antimicrobial observations found were statistically evaluated by using analysis of variance (ANOVA) by using the IBM SPSS Statistics 20 software. Duncan's post hoc tests were performed to observe the differences between groups at $5 \%$ significance level.

\section{RESULTS AND DISCUSSION}

\section{Physicochemical properties}

Saponification value (SV) is a good tool for the determination of average molecular weight of fatty acid in a triglyceride ${ }^{39}$. Lower the SV of the oil the large is the chain length of triglyceride and hence molecular weight. From Table 2 the highest saponification values was shown by $B$. persicum and $R$. pseudoacacia followed by $T$. officinale,
A. precatorius, D. deltoidea, M. neglecta, P. hexandrum and $A$. virdis. lodine value gives the idea of degree of unsaturation. As listed in Table 2 R. pseudoacacia, $T$. officinale and $M$. neglecta shows maximum iodine values followed by $B$. persicum, $D$. deltoidea, $P$. hexandrum and $A$. virdis respectively.

Table 2: Oil \% (w/w), S.V and I.V of P. hexandrum, B. persicum, A. precatorius, T. officinale, A. virdis, $D$. deltoidea, M. neglecta and $R$. pseudoacacia seed oils

\begin{tabular}{lccc}
\hline \multicolumn{1}{c}{ Plants } & $\begin{array}{c}\text { Oil percentage } \\
(\mathrm{w} / \mathrm{w})\end{array}$ & $\begin{array}{c}\text { Saponification } \\
\text { value }\end{array}$ & $\begin{array}{c}\text { lodine } \\
\text { value }\end{array}$ \\
\hline P. hexandrum & 6.9 & 120.60 & 59.88 \\
B. persicum & 6.83 & 177.70 & 93.90 \\
A. precatorius & 16.78 & 122.19 & 56.93 \\
T. officinale & 3.8 & 127.49 & 109.83 \\
A. virdis & 2.38 & 117.52 & 53.98 \\
D. deltoida & 1.6 & 121.13 & 89.20 \\
M. neglecta & 17.19 & 121.13 & 109.47 \\
R. pseudoacacia & 8.44 & 151.70 & 161.90 \\
\hline
\end{tabular}

\section{Fatty acid composition}

The composition of fatty acid was determined by gas chromatography (GC) and individual fatty acids were identified by mass spectroscopy (MS) as given in (Fig. S2 to Fig. S16). Fatty acid composition of all seed oils of plants are shown in Table 3. The seed oils were mostly dominant in unsaturated acids with $(62.7 \%, 84.6 \%, 64.0 \%, 65.8 \%, 60.9 \%, 62.2 \%$, $62.6 \%$ and $77.5 \%$ ) composition of total unsaturated fatty acids (TUFA) for $P$. hexandrum, B. persicum, $A$. precatorius, $T$. officinale, $A$. virdis, $D$. deltoidea, $M$. neglecta and $R$. pseudoacacia respectively. Oleic acid was the most dominant monounsaturated fatty acid in $A$. precatorius, $A$. virdis, $P$. hexandrum and $D$. deltoidea with $(60.2 \%, 58.9 \%, 57.5 \%$ and $21.7 \%$ ) respectively, while as it is found in smaller amounts in T. officinale $6.0 \%$, M. neglecta $3.7 \%$ and R. pseudoacacia 1.3\%. The dominant amount $64 \%$ petroselinic acid was found in seed oil of B. persicum. Among polyunsaturated fatty acids, linoleic acid was most dominant in T. officinale, M. neglecta, R. pseudoacacia, D. deltoidea and B. persicum with $(59 \%, 57.4 \%, 45.6 \%, 39.3 \%$ and $15.9 \%)$ respectively, while it is found in minor amount in $P$. hexandrum $3.7 \%$ and $A$. virdis $0.9 \%$. The linolenic acid was dominant in R.pseudoacacia $30.6 \%$ while low percentage in $P$. hexandrum $1.1 \%$, A. precatorius $0.6 \%$ and $M$. neglecta $0.7 \%$. Among SFAs palmitic and stearic acid were the main fatty acids found. Palmitic acid includes (25.6\%, 22.7\%, 20.2\%, 14.9\%, $11.1 \%, 11.0 \%, 8.1 \%$ and $3.9 \%$ ) for M. neglecta, $P$. hexandrum, D. deltoidea, A. virdis, A. precatorius, 
T. officinale, B. persicum and R. pseudoacacia respectively and stearic acid includes $(10.7 \%, 8.1 \%$, $4.8 \%, 4.5 \%, 3.5 \%, 3.5 \%$ and $1.2 \%$ ) for P. hexandrum, M. neglecta, T. officinale, $A$. precatorius, $A$. virdis, $D$. deltoidea and $R$. pseudoacacia respectively. The fatty acid composition of $P$. hexandrum is quiet similar to that of Sterculia tomentosa from Sudan ${ }^{40}$.
In B. persicum and R. pseudoacacia the major fatty acids found are comparatively similar in composition as reported in Olea europea from Palestine and Temperate growing Cannabis sativa respectively ${ }^{41,42}$. The fatty acid composition of $D$. deltoidea is similar to cotton seed which is used in pharmaceutical and cosmetic preparation ${ }^{43}$.

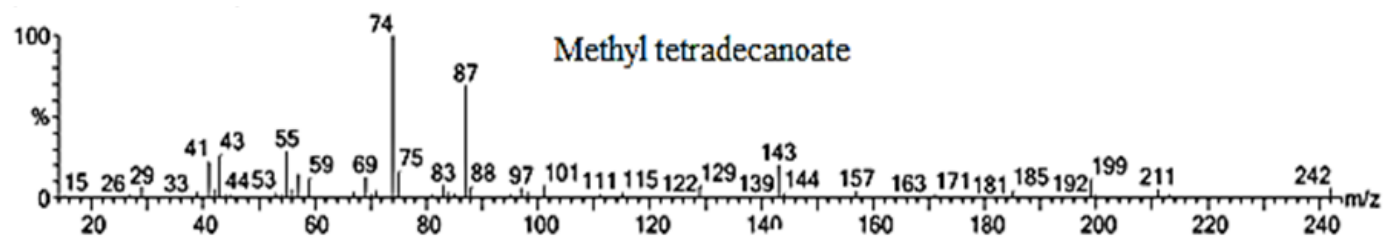

Fig. S2. Mass spectrum of Methyl tetradecanoate

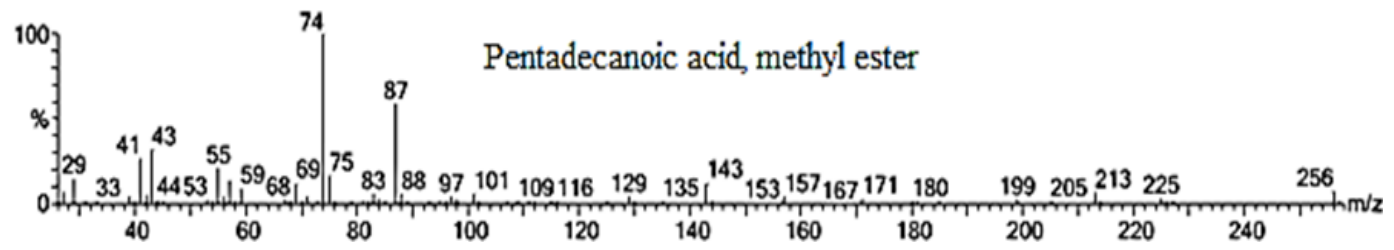

Fig. S3. Mass spectrum of Pentadecanoic acid, methyl ester

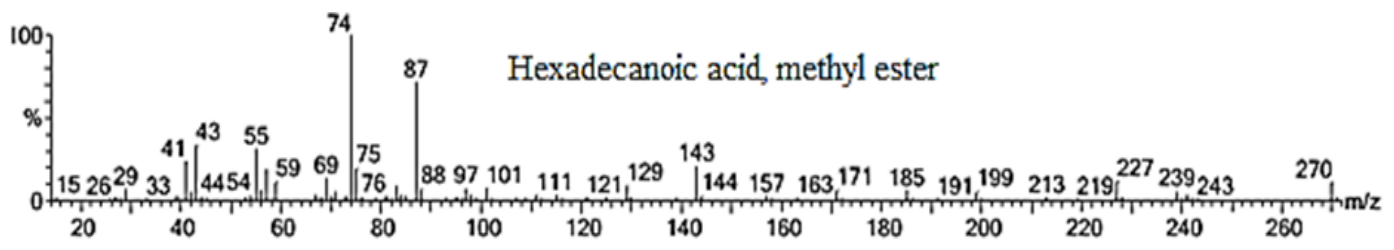

Fig. S4. Mass spectrum of Hexadecanoic acid, methyl ester

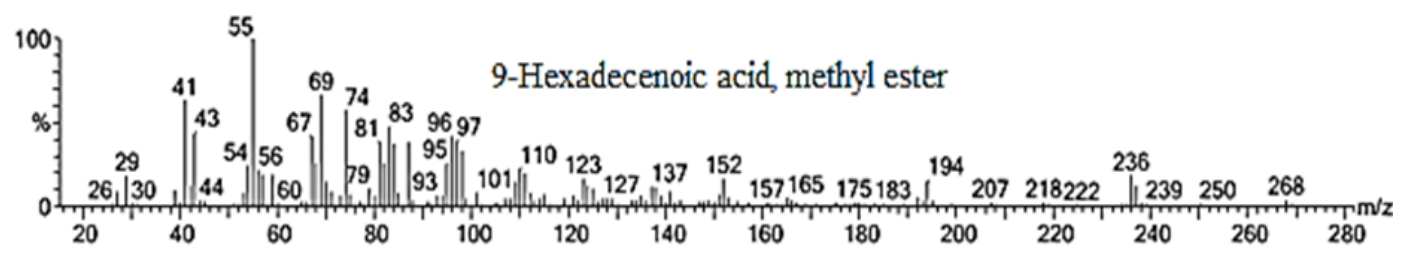

Fig. S5. Mass spectrum of 9-Hexadecenoic acid, methyl ester

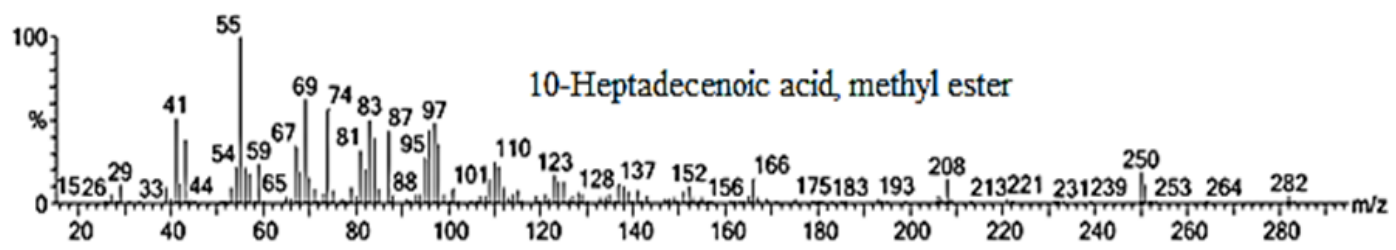

Fig. S6. Mass spectrum of 10-Heptadecenoic acid, methyl ester

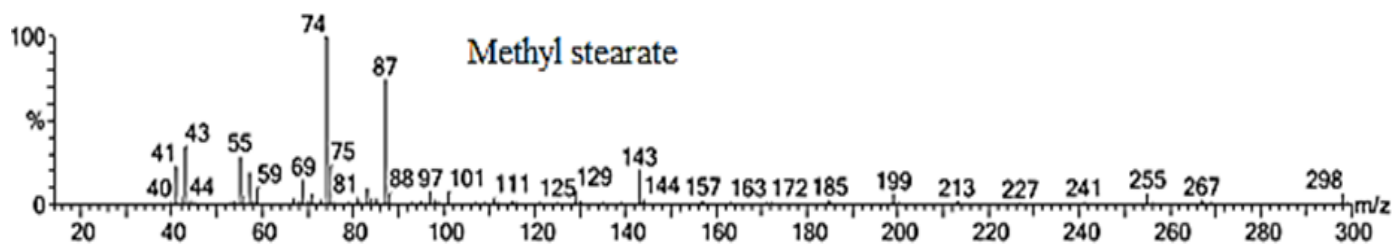

Fig. S7. Mass spectrum of Methyl stearate 


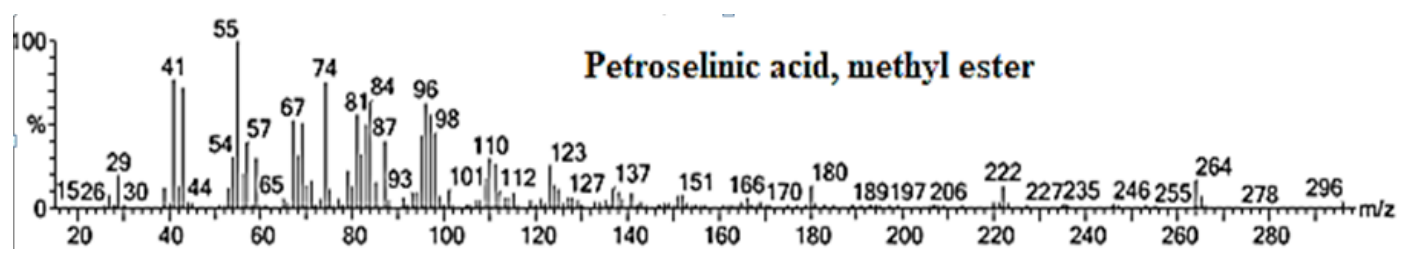

Fig. S8. Mass spectrum of Petroselinic acid, methyl ester
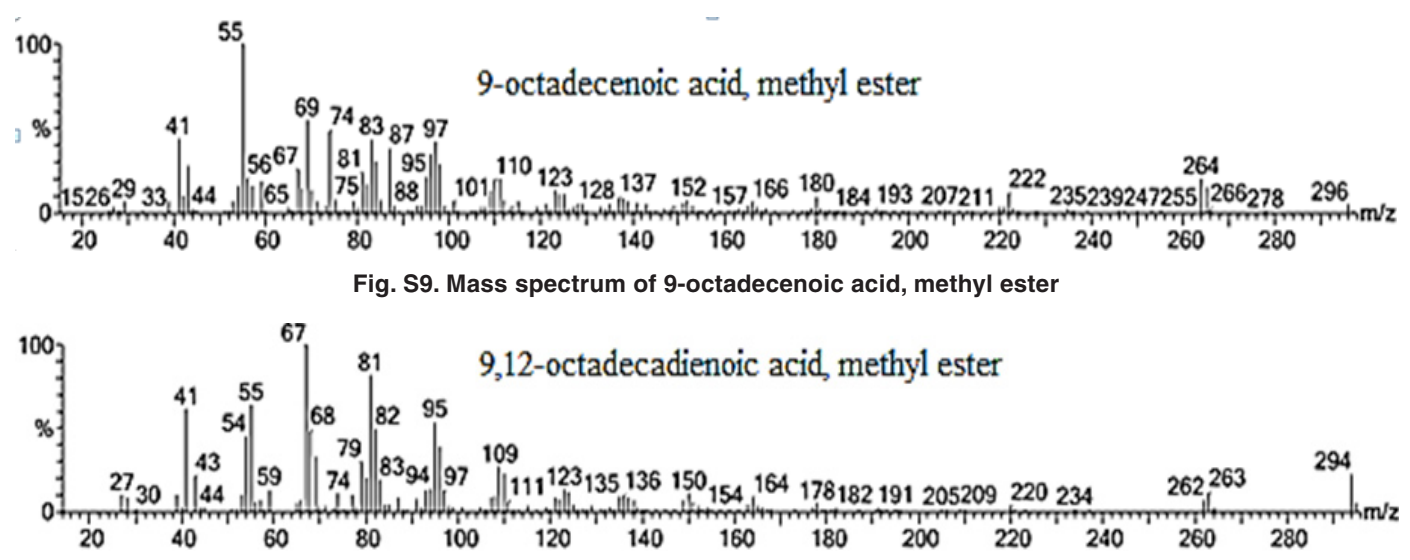

Fig. S10. Mass spectrum of 9,12-octadecadienoic acid, methyl ester

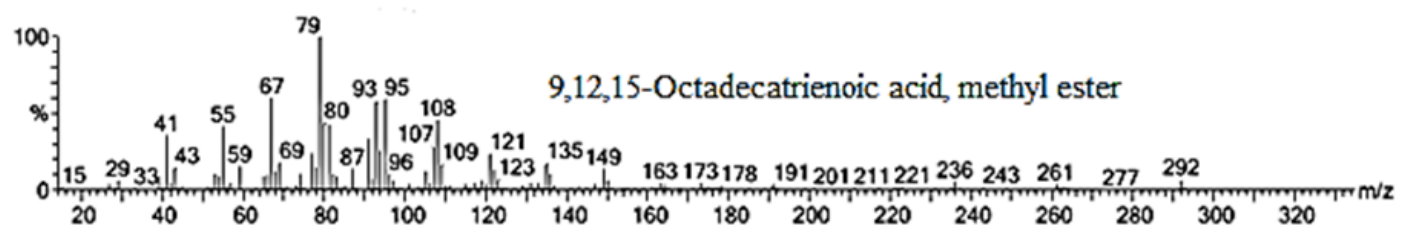

Fig. S11. Mass spectrum of 9,12,15-octadecatrienoic acid, methyl ester
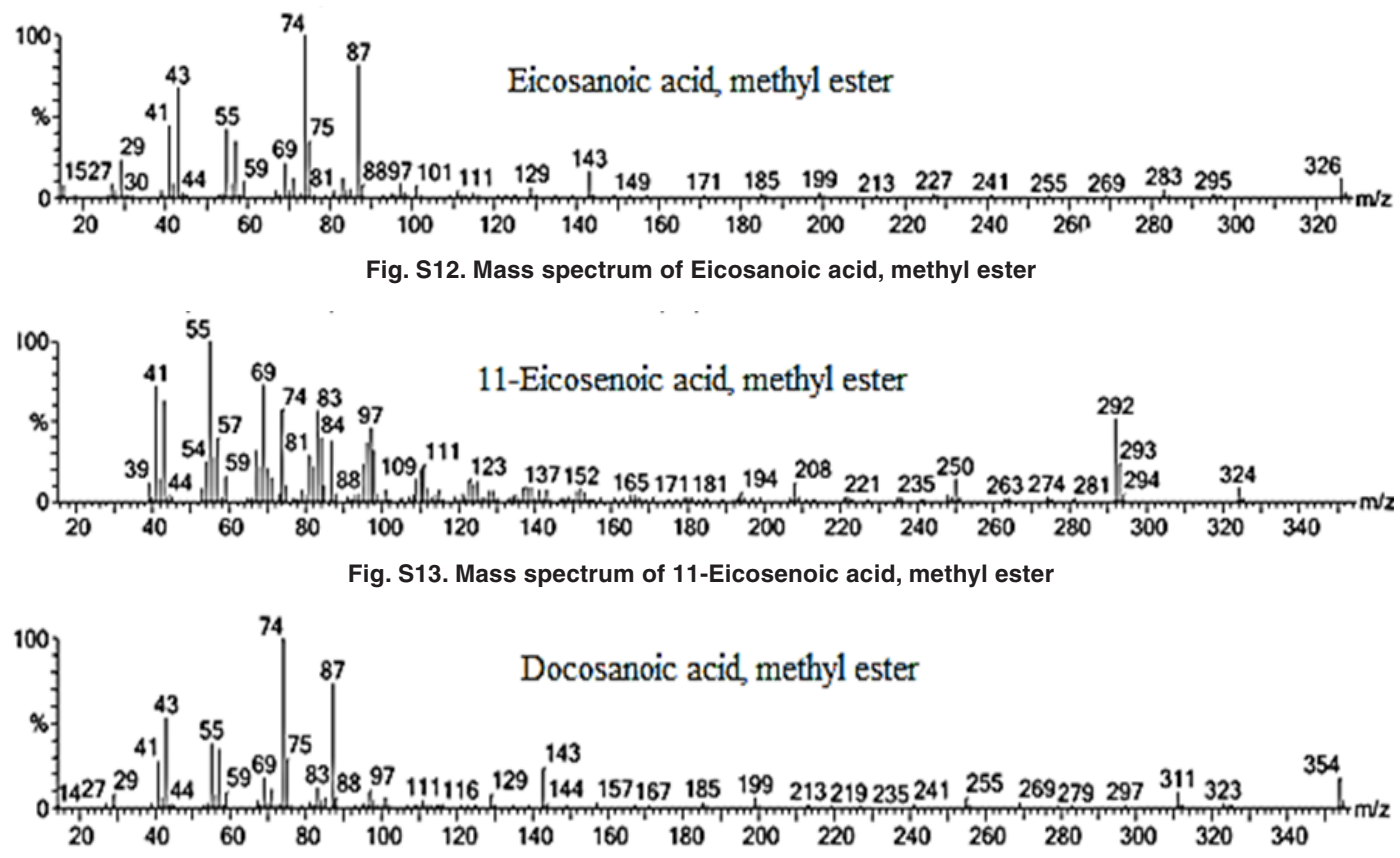

Fig. S14. Mass spectrum of Docosanoic acid, methyl ester 


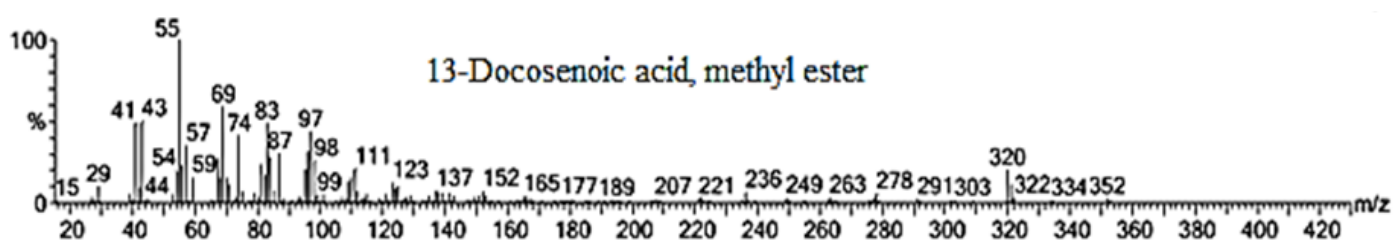

Fig. S15. Mass spectrum of 13-Docosenoic acid, methyl ester

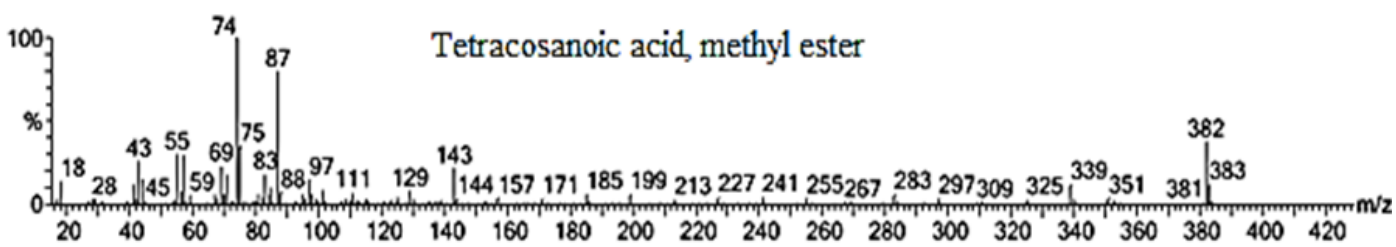

Fig. S16. Mass spectrum of Tetracosanoic acid, methyl ester

Table 3. Fatty acid composition of seed oils of $P$. hexandrum, B. persicum, A. precatorius, T. officinale, $A$. virdis, $D$. deltoidea, $M$. neglecta and $R$. pseudoacacia

\begin{tabular}{|c|c|c|c|c|c|c|c|c|}
\hline $\begin{array}{l}\text { Common and systematic } \\
\text { names }\end{array}$ & P. hexandrum & B. persicum $A$ & A. precatorius & $\begin{array}{c}\text { Area }(\%) \\
\text { T. officinale }\end{array}$ & A. virdis & D. deltoida & a M. neglecta & R.pseudoacacia \\
\hline Myristic acid14:0 & 0.4 & - & - & - & 0.6 & 1.2 & 0.5 & - \\
\hline Pentadecanoic acid 15:0 & - & - & - & - & 1.1 & - & - & - \\
\hline Palmitic acid 16:0 & 22.7 & 8.1 & 11.1 & 11.0 & 14.9 & 20.2 & 25.6 & 3.9 \\
\hline Palmitoleic acid16:1 & - & & - & 0.8 & 0.5 & 0.7 & 0.3 & - \\
\hline Heptadecenoic acid 17:1 & - & - & - & - & - & - & 0.5 & - \\
\hline Stearic acid 18:0 & 10.7 & - & 4.5 & 4.8 & 3.5 & 3.5 & 8.1 & 1.2 \\
\hline Petroselinic acid $18: 1 \Delta 6$ & - & 64.0 & - & - & - & - & - & - \\
\hline Oleic acid 18:1 $\Delta 9$ & 57.5 & - & 60.2 & 6.0 & 58.9 & 21.7 & 3.7 & 1.3 \\
\hline Linoleic acid 18:2 & 3.7 & 15.9 & - & 59.0 & 0.9 & 39.3 & 57.4 & 45.6 \\
\hline Linolenic acid 18:3 & 1.1 & - & 0.6 & - & - & - & 0.7 & 30.6 \\
\hline Arachidic acid $20: 0$ & 0.4 & 0.7 & 1.4 & 3.1 & 1.4 & 0.9 & - & - \\
\hline Gondoic acid 20:1 & - & 1.5 & 2.6 & - & 0.6 & 0.5 & - & - \\
\hline Behenic acid 22:0 & - & 0.6 & 7.1 & 2.3 & - & 2.3 & - & - \\
\hline Erucic acid22:1 & - & 3.2 & 0.6 & - & - & - & - & - \\
\hline Lignoceric acid24:0 & - & 0.3 & 3.5 & - & - & 1.2 & - & - \\
\hline Total unsaturated acids & 62.7 & 84.6 & 64.0 & 65.8 & 60.9 & 62.2 & 62.6 & 77.5 \\
\hline Total saturated acids & 33.8 & 9.7 & 27.6 & 21.2 & 21.5 & 29.3 & 34.2 & 5.1 \\
\hline
\end{tabular}

\section{Functional group analysis by FTIR}

Transmission spectra of defatted seed extracts of $P$. hexandrum, B. persicum, A. precatorius, T. officinale, A. virdis, D. deltoidea, M. neglecta and R. pseudoacacia are shown in (Fig. S17) and peak values are given in (Table 4). The IR peaks for $B$. persicum seed extracts are pointed out while as IR spectrum of rest of seed extracts are given in (Fig. S17). The presence of various functional groups as depicted by IR confirm various active substances present e. g defatted seed extracts of these plants which could be responsible for their biological activities.

\section{Antifungal activity of defatted seed extracts}

All the defatted seed extracts showed good antifungal activity at all concentrations, but most dominant activity was shown at Standard solution $S$ (Table 5). The defatted seed extracts of T. officinale, $B$. persicum and $M$. neglecta displayed most dominant effect with zone of inhibition $19.53 \mathrm{~mm}, 18.82 \mathrm{~mm}$ and $18.61 \mathrm{~mm}$ respectively against $A$. niger with respect to nystatin $20.36 \mathrm{~mm}$. Against $A$. fumigates the inhibition zone was found to be $21.42 \mathrm{~mm}, 21.06$ $\mathrm{mm}$ and $21.05 \mathrm{~mm}$ for T. officinale, B. persicum and $M$. neglecta respectively with nystatin displayed $25.56 \mathrm{~mm}$ inhibition zone. Against $P$. marneffei the most dominant effect was shown by $T$. officinale $24.96 \mathrm{~mm}, M$. neglecta $24.22 \mathrm{~mm}$ followed by R. pseudoacacia $23.93 \mathrm{~mm}$, B. persicum $23.81 \mathrm{~mm}$, A. precatorius $22.46 \mathrm{~mm}$ with respect to nystatin e.g $28.35 \mathrm{~mm}$ (Table 5). 
RAUF et al., Orient. J. Chem., Vol. 36(1), 44-53 (2020)
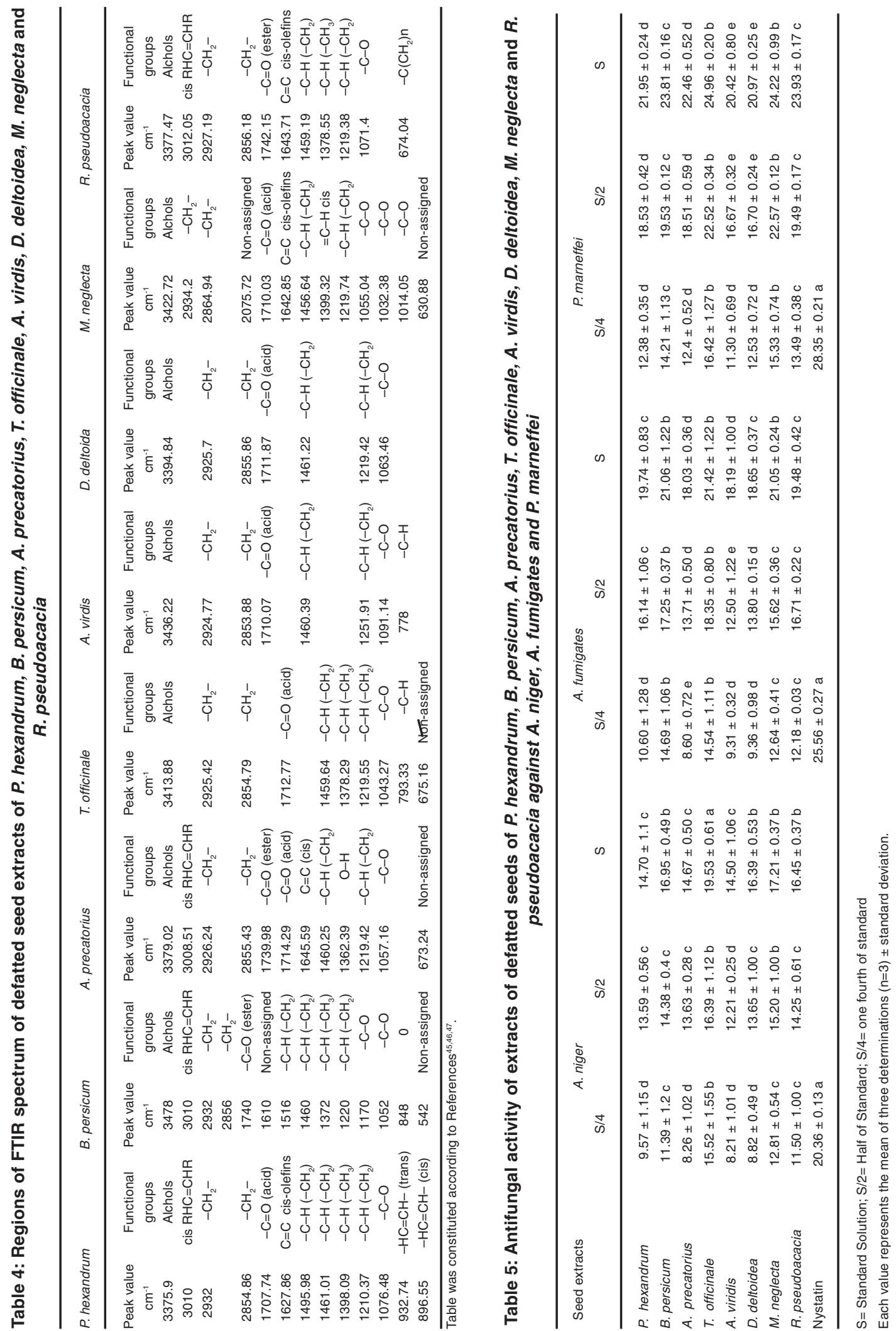


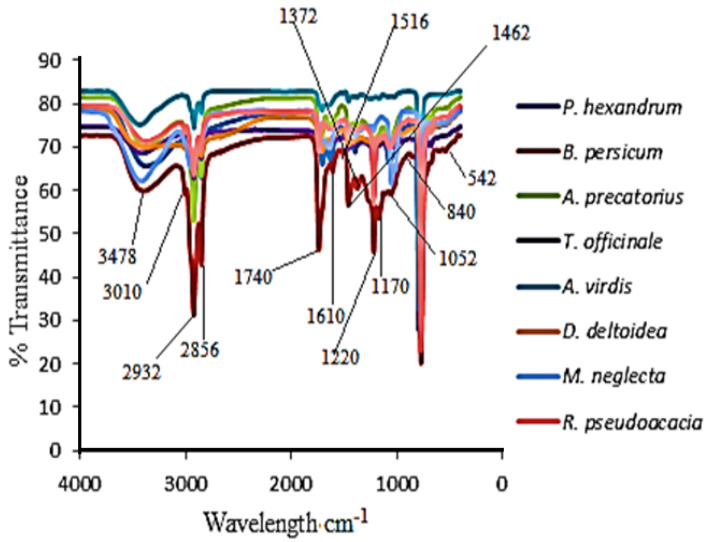

Fig. S17. FTIR analysis of the defatted seed extracts of P. hexandrum, B. persicum, A. precatorius, T. officinale, $A$. virdis, $D$. deltoidea, $M$. neglecta and $R$. pseudoacacia

Table 6: Antibacterial activity of extracts of defatted seeds of $P$. hexandrum, B. persicum, A. precatorius, T. officinale, $A$. virdis, $D$. deltoidea, $M$. neglecta and R. pseudoacacia against E. coli, S. aureus and $P$. aeruginosa

\begin{tabular}{lcccc} 
S. No. & Seed extracts & \multicolumn{3}{c}{ Minimal Inhibitory Concentration } \\
& & E. coli & $\begin{array}{l}(\mu \mathrm{gg} / \mathrm{ml}) \\
\text { S. aureus }\end{array}$ & P. aeruginosa \\
\hline 1 & P. hexandrum & 250 & 250 & 250 \\
2 & B. persicum & 125 & 250 & 125 \\
3 & A. precatorius & 125 & 125 & 250 \\
4 & T. officinale & 250 & 250 & 125 \\
5 & A. viridis & 250 & 125 & 250 \\
6 & D. deltoidea & 250 & 125 & 125 \\
7 & M. neglecta & 125 & 250 & 125 \\
8 & R. pseudoacacia & 500 & 500 & 250 \\
9 & Streptomycin & 5 & 5 & 10 \\
\hline
\end{tabular}

Antibacterial activity of defatted seed extracts

The results of this study are shown in (Table 6). The defatted seed extracts of B. persicum, $A$. precatorius and $M$. neglecta displayed lowest MIC
$125 \mu \mathrm{g} / \mathrm{mL}$, while other defatted extracts showed MIC $250 \mu \mathrm{g} / \mathrm{mL}$ except $R$. pseudoacacia which showed $500 \mu \mathrm{g} / \mathrm{mL}$. Inhibition against $S$. aureus defatted seed extracts of $A$. precatorius, $A$. virdis and $D$. deltoidea showed lowest MIC $125 \mu \mathrm{g} / \mathrm{mL}$, while defatted extracts of other plants (Table 6) showed MIC $250 \mu \mathrm{g} / \mathrm{mL}$ except $R$. pseudoacacia showed $500 \mu \mathrm{g} / \mathrm{mL}$. Against P. aeruginosa (Gram-negative bacteria) defatted seed extracts of $B$. persicum, T. officinale, $D$. deltoidea and M. neglecta showed lowest MIC $125 \mu \mathrm{g} / \mathrm{mL}$ while other seed extracts of plants showed MIC $250 \mu \mathrm{g} / \mathrm{mL}$.

\section{CONCLUSION}

From the above results, this research concluded that these plants contains high percentage of oleic, linoleic and significant amount of palmitic acids. Moreover the defatted seed extracts showed powerful antifungal and antibacterial activities. Based on above results we conclude that seed extracts of these plants could be used in food industry, cosmetic industry and source of new natural fungicides and bactericides in pharmaceutical industry. However further work need to be carried on isolation, purification and characterization of active compounds in defatted seed extracts.

\section{ACKNOWLEDGEMENT}

We are grateful to University Sophisticated Instrumentation Facility (USIF), and instrumentation faculty in Chemistry department, A.M.U, Aligarh for providing the required facilities to complete out this work. Prof. Sajad and Dr. Tahir are duly acknowledged for helping and guiding in collection and identification of seeds.

\section{Conflict of interest}

The authors proclaim no conflict interest.

\section{REFERENCES}

1. Sharififar, F.; Yassa, N.; Mozaffarian, V. Pak. J. Pharma. Sci., 2010, 23, 300-304.

2. Arora, R.; Gill, N. S.; Kaur, S.; Jain, A. D. J. Pharmacol. Toxicol., 2011, 6, 580-588.

3. Escudero, N. L.; De Arellano, M. L.; Fernández, S.; Albarracín, G.; Mucciarelli, S. Plant Foods Human Nut., 2003, 58, 1-10.

4. Gowdey, G.; Lee, R. K.; Carpenter, W. M. Oral Pathol. Oral Radio. Endodon., 1995, 79, 64-67.

5. Lewis, W. H. Plants used medically by indigenous peoples. In Phytochem. Res. Med. Agri. 1992, (33-74). Springer, Boston, MA.

6. Rajaram, N.; Janardhanan, K. Plant Foods
Human Nut., 1992, 42, 285-290.

7. Choi, U. K.; Lee, O. H.; Yim, J. H.; Cho, C. W.; Rhee, Y. K.; Lim, S. I.; Kim, Y. C. Int. J. Mol. Sci., 2010, 11, 67-78.

8. Ahmed, S. A.; Hanif, S.; Iftkhar, T. Open J. Med. Microbio., 2013, 3, 164-171.

9. Jain, S. K. 2nd Revised Edition, National Book Trust, New Delhi, India., 1975, 1-180.

10. Mayer, M.; Zbinden, M.; Vogl, C. R.; Ivemeyer, S.; Meier, B.; Amorena, M.; Maeschli, A.; Hamburger, M.; Walkenhorst, M. J. Ethnobio. Ethnomed., 2017, 13, 1. 
11. Okoko, I. I.; Osinubi, A.; Olabiyi, O.; Kusemiju, T.; Noronha, C.; Okanlawon, A. Endo. Pract., 2010, 16, 554-560.

12. Mensah, A. Y.; Bonsu, A. S.; Fleischer, T. C. Int. J. Pharm. Sci . Rev. Res., 2011, 6, 9-13.

13. Kumar, A.; Lakshman, K.; Jayaveera, K. N.; Nandeesh, R.; Manoj, B.; Ranganayakulu, D. Arch. Bio. Sci., 2010, 62, 185-189.

14. Sofi, P. A.; Zeerak, N. A.; Singh, P. Turk. J. Bio., 2009, 33, 249-258.

15. Sultana, S.; Ripa, F. A.; Hamid, K. Pak. J. Bio. Sci., 2010, 13, 340-343.

16. Subhash, C.; Sarla, S.; Mridul, D. Int. J. Res. Pharm., 2012, 3, 152-156.

17. Mayer, M.; Zbinden, M.; Vogl, C. R.; Ivemeyer, S.; Meier, B.; Amorena, M.; Maeschli, A.; Hamburger, M.; Walkenhorst, M. J. Ethnobio. Ethnomed., 2017, 13, 1.

18. Jackson, D. E.; Dewick, P. M. Phytochem., 1984, 23, 1147-1152.

19. Canel, C.; Dayan, F. E.; Ganzera, M.; Khan, I. A.; Rimando, A.; Burandt Jr, C. L.; Moraes, R. M. Planta Med., 2001, 67, 97-99.

20. Moraes, R. M.; Bedir, E.; Barrett, H.; Burandt Jr, C.; Canel, C.; Khan, I. A. Planta Medica., 2002, 68, 341- 344.

21. Cobb, M. W. J. Amer. Acad. Dermatol., 1990, 22, 547-566.

22. Beutner, K. R. In Sem. Dermatol., 1990, 9,148-151.

23. Rosu, A. F.; Bita, A.; Calina, D.; Rosu, L.; Zlatian, O.; Calina, V. Eur. J. Hospit. Pharm. Sci. Pract., 2012, 19, 216-216.

24. Mir, M. A.; Sawhney, S. S.; Jassal, M. S. Amer. J. Adv. Drug Deliv., 2015, 3, 160-180.

25. Schutz, K.; Carle, R.; Schieber, A. J. Ethnopharmacol., 2006, 107, 313-323.

26. Lopez Miranda, J.; Badimon, L.; Bonanome, A.; Lairon, D.; Kris Etherton, P. M.; Mata, P.; Perez Jimenez, F. Nut. Rev., 2006, 64, S2-S12.

27. Chen, S. H.; Chuang, Y. J. Analytica Chimica Act., 2002, 465, 145-155.

28. Soybean, I. Advan. Agronom., 2004, 84, 273-306.
29. Li, X. M.; Luo, X. G.; Si, C. L.; Wang, N.; Zhou, H.; He, J. F.; Zhang, T. C. Eur. J. Med. Chem., 2015, 96, 436-444.

30. Valle Jr, D. L.; Andrade, J. I.; Puzon, J. J. M.; Cabrera, E. C.; Rivera, W. L. Asian Pacific J. Trop. Biomed., 2015, 5, 532-540.

31. Zampini, I. C.; Vattuone, M.A.; Isla, M. I. J. Ethnopharmacol., 2005, 102, 450-456.

32. Chitwood, D. J. Annu. Rev. Phytopathol., 2002, 40, 221-249.

33. Nengroo, Z. R.; Rauf, A. Ind. Crops Prod., 2019, 140, 111596.

34. Parveen, H.; Rauf, A. Ind. Crops Prod., 2008, 27, 118-122.

35. Sharma, S.; Gangal, S.; Rauf, A. Ind. Crops Prod., 2009, 30, 325-328.

36. Link, W. E. Off. Amer. Oil Chem. Soc., 1973, Methods Da 15-48 and Da 16-48.

37. Bauer, A. W.; Kirby, W. M. M.; Sherris, J. C.; Turck, M. Amer. J. Clin. Pathol., 1966, 45, 493-496.

38. Wiegand, I.; Hilpert, K.; Hancock, R. E. Nat. Protocol., 2008, 3(2), 163.

39. Nehdi, I. A.; Sbihi, H.; Tan, C. P.; Zarrouk, H.; Khalil, M. I.; Al-Resayes, S. I. Ind. Crops Prod., 2012, 36, 54-58.

40. Henry, A. J.; Grindley, D. N. J. Soc. Chem. Ind., 1944, 63, 188-190.

41. Da Porto, C.; Decorti, D.; Tubaro, F. Ind. Crops Prod., 2012, 36(1), 401-404.

42. Lodolini, E. M.; Polverigiani, S.; Ali, S.; Mutawea, M.; Qutub, M.; Arabasi, T.; Pierini, F.; Abed, M.; Neri, D. J. Oleo Sci., 2017, 16184.

43. Alvarez, A. M. R.; Rodríguez, M. L. G. Grasas Aceite., 2000, 51, 74-96.

44. Guillen, M. D.; Cabo, N. J.Am. Oil Chem. Soc., 1997, 74, 1281-1286.

45. Silverstein, R. M.; Bassler, G. C.; Kiemle, D. J. Hoboken, USA: John Wiley \& Sons., 2005, (Chapter 2).

46. Vlachos, N.; Skopelitis, Y.; Psaroudaki, M.; Konstantinidou, V.; Chatzilazarou, A.; Tegou, E. Anal. Chim. Act., 2006, 573, 459-465. 